\title{
Airway Inflammation Is Present during Clinical Remission of Atopic Asthma
}

\author{
LEON M. VAN DEN TOORN, SHELLEY E. OVERBEEK, JOHAN C. DE JONGSTE, KAROLINA LEMAN, \\ HENK C. HOOGSTEDEN, and JAN-BAS PRINS
}

Department of Pulmonary Medicine and Paediatrics/Paediatric Respiratory Medicine, Erasmus University Medical Center Rotterdam, The Netherlands

\begin{abstract}
Symptoms of atopic asthma often disappear at puberty. However, asthmatic subjects in clinical remission will frequently have a relapse later in life. The aim of this study was to investigate whether subjects in clinical remission of atopic asthma have persistent airway inflammation and/or airway remodeling. Bronchial biopsies were obtained from subjects in clinical remission, asthmatic subjects, and healthy control subjects. The presence and/or activation state of eosinophils, mast cells, macrophages, T lymphocytes, interleukin (IL)-5, eotaxin, and inducible nitric oxide synthase (iNOS) were analyzed. Results were compared with less invasive indicators of airway inflammation. Also aspects of airway remodeling were determined. Eosinophils, T cells, mast cells, and IL-5 were significantly elevated in the airway mucosa of subjects in remission compared with control subjects. Also, blood eosinophil cell counts were significantly higher in subjects in clinical remission. Blood eosinophil cell counts, exhaled nitric oxide (eNO) levels, and bronchial response to adenosine-5'-monophosphate correlated significantly with the quantity of tissue eosinophils. Significant airway remodeling was found in subjects in clinical remission. Our study has shown ongoing airway inflammation and airway remodeling in adolescents in clinical remission of atopic asthma. Subclinical airway inflammation may well determine the risk of an asthma relapse later in life.
\end{abstract}

Keywords: atopic asthma; remission; inflammation; iNOS; remodeling

Symptoms of atopic asthma often begin in early childhood and mostly improve or even seem to disappear at puberty $(1,2)$. However, a considerable proportion of asthmatic subjects in clinical remission will have a relapse later in life (1). Several studies have shown spirometric abnormalities and bronchial hyperresponsiveness (BHR) to methacholine (MCh) or cold air challenge during clinical remission of asthma $(3,4)$. It is unknown whether these functional abnormalities, which are supposed to be indicative of asthma severity with respect to symptomatic asthma, reflect persistent activity of the airways inflammatory process or merely indicate structural changes of the airways as a consequence of childhood asthma. These structural changes, known as airway remodeling, are probably early events in the course of the disease that appear to progress. The process of remodeling leads to thickening of the airway wall (5-7). The exact physiologic consequences of airway wall thickening are, however, incompletely understood (8). If airway wall thickening is present in subjects in clinical remission

(Received in original form June 30, 2000; accepted in final form July 17, 2001)

Supported by Grant 96.20 from the Netherlands Asthma Foundation.

Correspondence and requests for reprints should be addressed to Leon M. van den Toorn, Department of Pulmonary Medicine, Erasmus Medical Center Rotterdam, 3015 GE Rotterdam, The Netherlands. E-mail: L.vandentoorn@planet.nl

Am J Respir Crit Care Med Vol 164. pp 2107-2113, 2001

DOI: $10.1164 / \mathrm{rccm} 2006165$

Internet address: www.atsjournals.org of asthma, it could at least in part account for the functional abnormalities including bronchial hyperresponsiveness, found during remission. On the other hand, ongoing active airway inflammation could have substantial impact on the risk of a relapse later in life. As a consequence, subjects with subclinical airway inflammation could benefit from anti-inflammatory treatment (8-10). Recently, we demonstrated elevated exhaled nitric oxide (eNO) levels and BHR to both MCh and adenosine-5'-monophosphate (AMP) during clinical remission of atopic asthma (11). With respect to eNO, increased expression of the inducible form of nitric oxide synthase (iNOS) is thought to underlie these elevated eNO levels $(12,13)$. Studies regarding the precise relationship between iNOS expression and eNO are, however, scarce (12).

Proof of persistent airway inflammation and remodeling during clinical remission could be furnished from the analysis of bronchial biopsy specimens. Evidence has been accumulated to suggest that allergen-reactive type $2 \mathrm{~T}$ helper (Th2) cells, with eosinophils and mast cells as main effector cells, orchestrate asthmatic airway inflammation $(14,15)$. The presence of eosinophils in the airway wall is apparently the most reliable feature of bronchial asthma that seems to be related to asthma severity (16). Along with interleukin (IL)-5, a Th2 cytokine, and eotaxin, a chemoattractant for eosinophils, eosinophil-derived products such as major basic protein (MBP) have been investigated as markers of eosinophil participation in the pathogenesis of asthma (17). Also, elevated numbers of bronchial mast cells have been found in the airway mucosa of atopic and nonatopic asthmatic subjects $(18,19)$. Release of mediators from mast cells such as granule-associated tryptase and chymase leads to immediate bronchoconstriction and enhances airway inflammation (19).

In healthy airways, the inflammatory response to such as inhaled allergens is suppressed by alveolar macrophages. In asthma, however, a deviant function of alveolar macrophages may contribute to the allergic immune response in the airways (20).

How numbers and activation state of these different cell types in the bronchial mucosa relate to less invasive markers of airway inflammation, including BHR, circulating eosinophils, and eNO, is largely unclear (21-23).

Remodeling of the airway mucosa and submucosa can be assessed by measurement of the reticular basement membrane (RBM) thickness (24) and extent of epithelial shedding (25). Also, collagen deposition (26) is a quantifiable aspect of airway remodeling.

To establish whether subjects in clinical remission of atopic asthma suffer from ongoing active airway inflammation and/or airway remodeling, we compared bronchial biopsy specimens of subjects with a long-standing clinical remission of atopic asthma with those of currently asthmatic subjects and of healthy control subjects. Biopsy findings were compared with noninvasive markers of airway disease. 


\section{Methods}

\section{Subjects}

Adolescents 18 to $25 \mathrm{yr}$ of age with atopic asthma were selected from the Sophia Children's Hospital discharged patients files. Clinical remission of atopic asthma was defined as reported complete absence of asthmatic symptoms in subjects not taking any asthma medication for at least 12 mo prior to the study. Eligible subjects were compared with patients with asthma who had persistent symptoms and used inhaled $\beta_{2}$-agonists on demand in order to relieve symptoms. Atopic asthma was previously diagnosed in all subjects according to ATS criteria (27). All subjects were lifelong nonsmokers in stable clinical condition and did not take inhaled steroids or antiallergic medication. Healthy nonsmoking adult volunteers without a history of asthma served as controls.

The study was approved by the Medical Ethics Committee of the Erasmus Medical Center Rotterdam.

\section{Study Design}

We performed a cross-sectional study with three visits on separate days. Spirometry values, eNO, MCh, and AMP responsiveness were obtained according to methods we described previously (11).

\section{Blood Eosinophils}

Venous blood eosinophil numbers were counted by means of hemocytometry. Reference values ranged from 0.04 to $0.1 \times 10^{9}$ cells $/ \mathrm{L}$.

\section{Bronchoscopy}

An experienced bronchoscopist (SEO) using an Olympus model BF IT 10 (Olympus, Tokyo, Japan) performed flexible bronchoscopy. At least five bronchial biopsies were obtained from segmental divisions of the main bronchi.

\section{Processing of Bronchial Biopsies}

Bronchial biopsies were embedded in Tissue-Tek II OCT medium (Miles, Naperville, IL), snap-frozen in liquid nitrogen, and stored at $-80^{\circ} \mathrm{C}$. Serial tissue sections $(6 \mu \mathrm{m})$ were cut on a HM-560 cryostat (Microm, Heidelberg, Germany). At least two sections $120 \mu \mathrm{m}$ apart from one biopsy specimen were placed on a poly-L-lysine-coated microscopic slide (Sigma Diagnostics, St. Louis, MO). Immunostaining was carried out with $\alpha$-CD4 (T helper cells), $\alpha$-CD8 (cytotoxic T cells), $\alpha$-CD25 (activated cells) and $\alpha$-CD69 (activated cells), $\alpha$-CD68 (macrophages), $\alpha$-MBP (Dako, Glostrup, Denmark), $\alpha$-IL-5, $\alpha$-eotaxin, $\alpha$-tryptase, $\alpha$-chymase (Chemicon Brunschwig Chemie, Amsterdam, The Netherlands), $\alpha$-iNOS (Santa Cruz Biotechnology, Santa Cruz, CA), and $\alpha$-collagen III.

Binding of the antibodies was detected by the immunoalkaline phosphatase antialkaline phosphatase (APAAP) method. Immunostained sections were analyzed with an image analysis system (Quantimed, Leica, Rijswijk, The Netherlands). With respect to the subepithelium, the program was set to analyze $100 \mu \mathrm{m}$ below the reticular basement membrane (RBM). The ratio of positive stained area divided by the total area analyzed was taken as measure for each immunohistochemical staining. RBM thickness was interactively measured at $20-\mu \mathrm{m}$ intervals over a 1-mm RBM length (24). The occupancy of RBM with epithelium was plotted as ratio of occupied membrane length divided by the total membrane length.

\section{Statistical Analysis}

Because of the skewed distribution of data, results are expressed as median values \pm SEM. Comparisons between groups were made by the Mann-Whitney test for unpaired samples. Correlation between different indices was made by Spearman's rank correlation test. A two-tailed $p$ value of equal to or less than 0.05 was considered significant. Data were analyzed using Statistical Package for the Social Science (SPSS, Chicago, IL USA).

\section{RESULTS}

Fifty-four subjects completed the study (19 subjects with atopic asthma, 18 subjects in clinical remission of atopic asthma, and 17 healthy control subjects). Subjects' character- istics are summarized in Table 1 . The median duration of clinical remission was $5 \mathrm{yr}$. Immunohistochemistry results are summarized in Table 2.

In both epithelium and subepithelium of airway mucosa specimens, MBP density was significantly greater in subjects in remission than in healthy control subjects $(\mathrm{p}<0.001$ and $\mathrm{p}=0.001$, respectively) (Figures 1 and 2 ). In bronchial epithelium of subjects in remission, there was more tryptase present than in that of healthy control subjects $(\mathrm{p}=0.001)$. In subepithelium, however, there was more tryptase detectable in subjects in remission than in control subjects and in patients with asthma ( $\mathrm{p}=0.008$ and $\mathrm{p}=0.025$, respectively) (Figures 3 and 4 ). Chymase density was greater in bronchial epithelium and subepithelium of subjects in remission than in that of healthy control subjects $(p=0.044$ and $p=0.05$, respectively).

There was no difference detectable in the presence of $\mathrm{CD}^{+}$ and $\mathrm{CD}^{+}$cells in both epithelium and subepithelium between the experimental groups. However, there were more activated $\mathrm{CD} 25^{+}$cells present in the subepithelium of subjects in remission when compared with control subjects $(\mathrm{p}=0.04)$. No such difference was detected for CD69. CD68 ${ }^{+}$cells were equally represented in subepithelium and epithelium in all three experimental groups.

In subepithelium, IL-5 density was significantly greater in subjects in remission than in healthy control subjects $(\mathrm{p}=$ 0.006). Eotaxin density was significantly greater in patients with asthma than in healthy control subjects $(\mathrm{p}=0.05)$, whereas intermediate levels were detected in subjects in remission. In the epithelium, densities of IL-5 and eotaxin were similar in all three groups. Density of iNOS was significantly greater in subepithelium of healthy subjects than in that of subjects in remission $(p=0.05)$. In the epithelium, iNOS density was greater in healthy subjects than in asthmatic subjects $(\mathrm{p}=0.05)$. No difference in iNOS density could be detected between healthy control subjects and subjects in clinical remission.

With respect to indices of remodeling, RBM thickness differed significantly between subjects in remission and control subjects $(10.9 \pm 1.3$ and $7.9 \pm 1.0 \mu \mathrm{m}$, respectively; $\mathrm{p}<0.001)$. Current asthmatic subjects showed a median thickness of $11.5 \pm$ $1.5 \mu \mathrm{m}$ (Figure 5, top panel). Furthermore, in subjects in remission the RBM occupancy with epithelium differed significantly from values obtained from control subjects (ratio: 0.67 and 0.83 , respectively; $\mathrm{p}<0.003$ ), and from values from current asthmatic subjects (median ratio: 0.50, $\mathrm{p}<0.03$ ) (Figure 5, bottom panel). Collagen type III density in biopsy specimens was not significantly different between the groups.

In peripheral blood, the number of eosinophils was significantly elevated in subjects in remission when compared with control subjects $\left(0.22 \pm 0.17 \times 10^{9} / 1\right.$ and $0.11 \pm 0.045 \times 10^{9} / 1$, respectively; $\mathrm{p}<0.001$ ) (Figure 6). Median eosinophil count in patients with asthma was $0.30 \pm 0.17 \times 10^{9} / 1$.

TABLE 1. SUBJECTS' CHARACTERISTICS*

\begin{tabular}{lccc}
\hline & $\begin{array}{c}\text { Asthmatic } \\
\text { Subjects } \\
(m=19)\end{array}$ & $\begin{array}{c}\text { Remission } \\
\text { Subjects } \\
(m=18)\end{array}$ & $\begin{array}{c}\text { Healthy } \\
\text { Control } \\
\text { Subjects } \\
(m=17)\end{array}$ \\
\hline Age, yr & $22 \pm 2$ & $21 \pm 2$ & $24 \pm 1$ \\
Sex, male:female & $13: 6$ & $15: 3$ & $9: 8$ \\
FEV $_{1}, \%$ pred & $88 \pm 12$ & $93 \pm 15$ & $105 \pm 13$ \\
FEV $_{1}$ reversibility & $11 \pm 1$ & $7 \pm 1$ & $4 \pm 1$ \\
\hline
\end{tabular}

* Variables are expressed as mean \pm SEM

${ }^{\dagger}$ Change in $\mathrm{FEV}_{1}$, expressed as increase in \% of predicted normal value after administration of $1 \mathrm{mg}$ terbutaline. 
TABLE 2. IMMUNOHISTOCHEMISTRY RESULTS*

\begin{tabular}{lccc}
\hline & $\begin{array}{c}\text { Asthmatic } \\
\text { Subjects }\end{array}$ & $\begin{array}{c}\text { Subjects in } \\
\text { Remission }\end{array}$ & $\begin{array}{c}\text { Healthy Control } \\
\text { Subjects }\end{array}$ \\
\hline Epithelium & & & \\
MBP & $0.023 \pm 0.0093^{\dagger}$ & $0.0082 \pm 0.0046^{\dagger}$ & $0.0007 \pm 0.0013$ \\
Tryptase & $0.0068 \pm 0.0020^{\ddagger}$ & $0.0119 \pm 0.0029^{\dagger}$ & $0.0025 \pm 0.0009$ \\
Chymase & $0.0100 \pm 0.0035$ & $0.013 \pm 0.0030^{\ddagger}$ & $0.0067 \pm 0.0016$ \\
CD4 & $0.001 \pm 0.0004$ & $0.0007 \pm 0.0002$ & $0.0009 \pm 0.0013$ \\
CD8 & $0.025 \pm 0.0045$ & $0.018 \pm 0.0068$ & $0.0281 \pm 0.0082$ \\
CD25 & $0.0093 \pm 0.0050$ & $0.0123 \pm 0.0032$ & $0.0058 \pm 0.0039$ \\
CD69 & $0.0095 \pm 0.0116$ & $0.0076 \pm 0.0182$ & $0.0123 \pm 0.0093$ \\
CD68 & $0.029 \pm 0.0054$ & $0.038 \pm 0.0067$ & $0.031 \pm 0.019$ \\
IL-5 & $0.038 \pm 0.0097$ & $0.036 \pm 0.018$ & $0.017 \pm 0.014$ \\
Eotaxin & $0.001 \pm 0.0013$ & $0.0002 \pm 0.0045$ & $0.0002 \pm 0.0005$ \\
INOS & $0.12 \pm 0.02$ & $0.15 \pm 0.03$ & $0.21 \pm 0.03$ \\
Collagen III & $0.078 \pm 0.011$ & $0.077 \pm 0.024$ & $0.062 \pm 0.009$ \\
Subepithelium & & & \\
MBP & $0.12 \pm 0.026^{\dagger}$ & $0.07 \pm 0.024^{\dagger}$ & $0.0042 \pm 0.0086$ \\
Tryptase & $0.037 \pm 0.0082$ & $0.075 \pm 0.012^{\S}$ & $0.022 \pm 0.010$ \\
Chymase & $0.014 \pm 0.0038$ & $0.018 \pm 0.0056^{\ddagger}$ & $0.0069 \pm 0.0033$ \\
CD4 & $0.0043 \pm 0.0040$ & $0.0025 \pm 0.0019$ & $0.0041 \pm 0.0027$ \\
CD8 & $0.022 \pm 0.0040$ & $0.014 \pm 0.0033$ & $0.019 \pm 0.004$ \\
CD25 & $0.0094 \pm 0.0126$ & $0.0356 \pm 0.0233^{\ddagger}$ & $0.0095 \pm 0.0041$ \\
CD69 & $0.0062 \pm 0.0198$ & $0.0156 \pm 0.0273$ & $0.0085 \pm 0.0063$ \\
CD68 & $0.058 \pm 0.0069$ & $0.069 \pm 0.013$ & $0.079 \pm 0.032$ \\
IL-5 & $0.025 \pm 0.0061$ & $0.022 \pm 0.0074^{\S}$ & $0.0066 \pm 0.0081$ \\
Eotaxin & $0.0011 \pm 0.0006^{\ddagger}$ & $0.0001 \pm 0.0087$ & $0.0001 \pm 0.0003$ \\
INOS & $0.041 \pm 0.006$ & $0.042 \pm 0.014^{\ddagger}$ & $0.065 \pm 0.016$ \\
Collagen III & $0.16 \pm 0.014$ & $0.19 \pm 0.016$ & $0.17 \pm 0.019$ \\
\hline & & &
\end{tabular}

* Variables are expressed as median density (ratio of positively stained area and total area) \pm SEM

$\dagger p=0.001$ versus healthy control subjects.

$\ddagger \mathrm{p}=0.05$ versus healthy control subjects.

$\S p=0.01$ versus healthy control subjects

$\| \mathrm{p}=0.05$ versus remission subjects.

In subjects in remission and those with asthma, a significant positive correlation was found between blood eosinophil cell counts and MBP density in both bronchial epithelium and subepithelium ( $\mathrm{r}=0.41, \mathrm{p}=0.017$ and $\mathrm{r}=0.45, \mathrm{p}=0.009$, respectively) (Figure 7, top panel). A similar correlation was observed for eNO values (11) and MBP density in bronchial epithelium and subepithelium of subjects in remission and patients with asthma $(\mathrm{r}=0.40, \mathrm{p}=0.022$ and $\mathrm{r}=0.35, \mathrm{p}=0.043$, respectively $)$ (Figure 7, bottom panel). $\mathrm{PD}_{20}$ AMP values correlated inversely with MBP density in subepithelium of subjects in remission and subjects with asthma $(\mathrm{r}=-0.37, \mathrm{p}=0.032)$. In contrast, no significant correlation could be found between $\mathrm{PD}_{20} \mathrm{MCh}$ values and MBP density in bronchial biopsy specimens. In subjects in remission and those with asthma, thickness of the RBM correlated with $\mathrm{PD}_{20}$ AMP $(\mathrm{r}=0.47, \mathrm{p}=0.038)$, whereas the relationship with $\mathrm{PD}_{20} \mathrm{MCh}$ was not significant $(\mathrm{r}=0.36, \mathrm{p}=0.1)$.

\section{DISCUSSION}

In this study we demonstrated the presence of an ongoing active inflammatory process in the airways during long-lasting clinical remission of atopic asthma, as reflected by significantly increased levels of MBP, tryptase, chymase, CD25, and IL-5 in bronchial epithelium and/or subepithelium. In addition, eosinophil cell counts in blood samples were significantly elevated during clinical remission compared with those in healthy control subjects. Less invasive indicators of airway inflammation such as blood eosinophils, eNO, and $\mathrm{PD}_{20}$ AMP showed a significant correlation with MBP density in biopsy specimens from subjects in remission and patients with asthma. We also found evidence of airway remodeling during clinical remission. There was a significant correlation between RBM thickness and bronchial hyperresponsiveness to AMP.
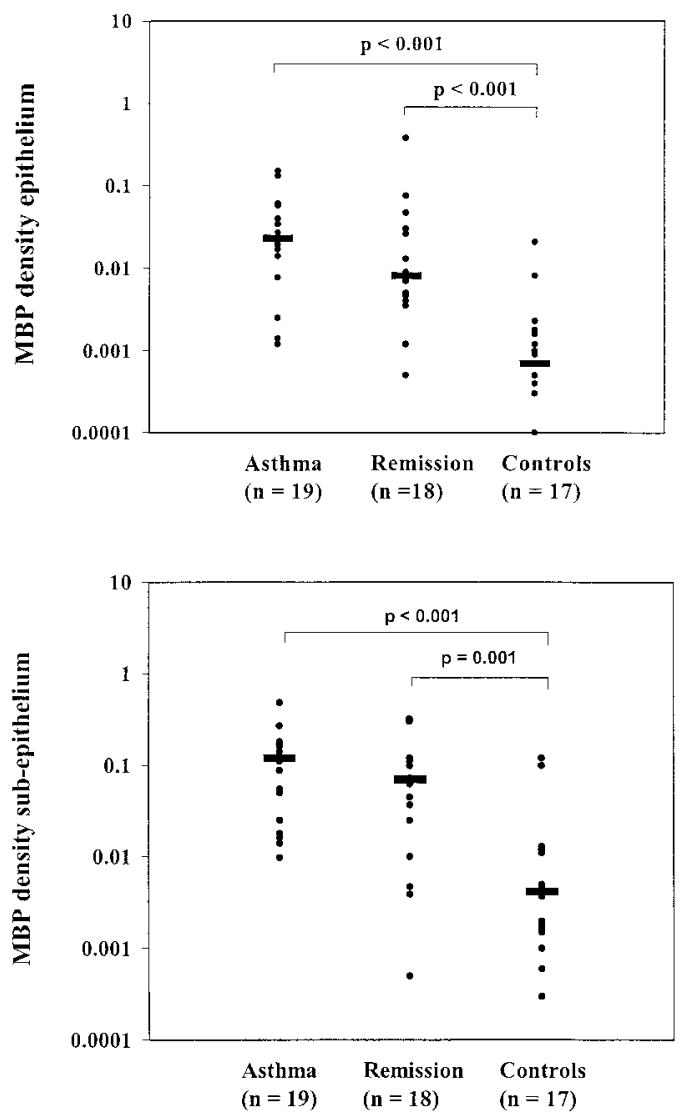

Figure 1. Ratio of area of Major Basic Protein (MBP) staining and total area of epithelium (top panel) and of subepithelium (bottom panel) in bronchial biopsy specimens from currently asthmatic subjects, subjects in clinical remission of atopic asthma, and healthy control subjects. Each closed circle represents one subject. Horizontal bars represent median values. $\mathrm{Y}$-axis shows values logarithmically.

Airway inflammation has been demonstrated in subjects with symptomatic asthma $(28,29)$. However, studies regarding the presence of inflammation in bronchial biopsy specimens from prolonged symptom-free subjects with a history of atopic asthma are lacking. Therefore, we applied a strict definition of clinical remission, where subjects were regarded in clinical remission if they reported complete absence of cough, chest discomfort, or breathlessness for at least $1 \mathrm{yr}$ preceding the study, and did not use any medication in order to control asthma symptoms. In our study population, the median duration of remission was $5 \mathrm{yr}$ with only one subject who had been in remission for just $1 \mathrm{yr}$. Not withstanding these strict inclusion criteria, we are the first to show direct evidence of substantial active airway inflammation, suggesting persistent disease in these otherwise asymptomatic subjects.

Increased numbers of eosinophils, one of the most important effector cells in atopic asthma, have been demonstrated in the bronchial mucosa of patients with asthma (17). We present similar findings in the bronchial mucosa of subjects in clinical remission. Also, elevated levels of tryptase- and chymase, constituents and markers of mast cells, were detected in the bronchial mucosa of subjects in remission compared with those of healthy control subjects. On the other hand, we found reduced tryptase density in the airway wall mucosa of subjects with asthma as compared with subjects in remission. This is suggestive of enhanced degranulation of mast cells in patients with asthma compared with subjects in clinical remission. Upon de- 

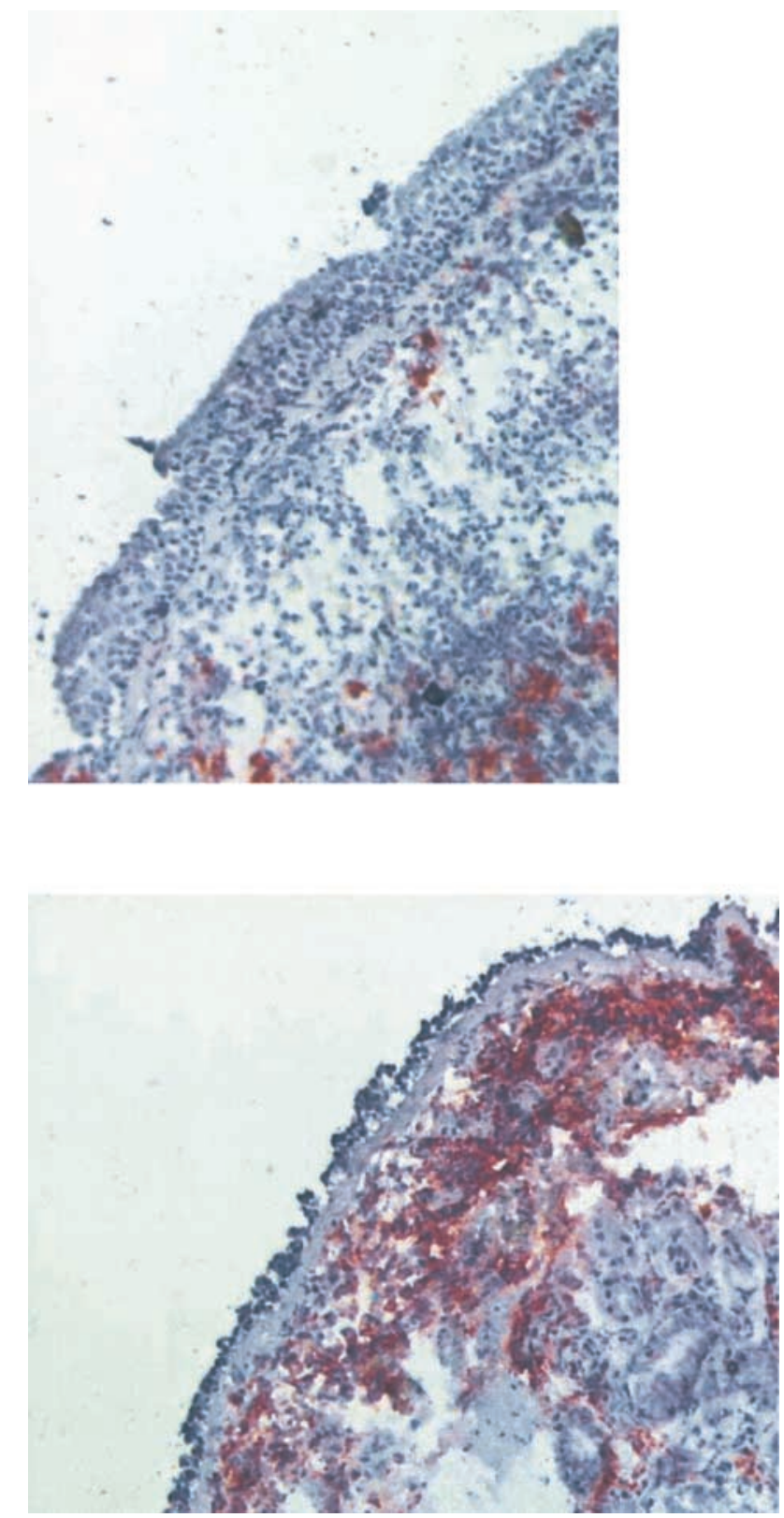

Figure 2. Bronchial biopsy specimen from a healthy control subject (top panel) and a subject in clinical remission of atopic asthma (bottom panel) immunostained with $\alpha$-Major Basic Protein (MBP). Notice the increased MBP-positive area (the red stain) and epithelial shedding in the subject in clinical remission.

granulation, mediators are diluted out into the tissue environment and rapidly degraded (30).

In the airway mucosa, there was no significant difference between the groups with respect to the presence of T cells. In previous studies, elevated T-cell numbers were found in the airway mucosa, even in patients in whom asthma was newly numbers of $\mathrm{T}$ cells in bronchial mucosa specimens $(32,33)$, or just an increase in activated T-cell numbers $(34,35)$. We found elevated levels of CD25 expression in bronchial subepithelium of subjects in remission compared with healthy subjects, which was not demonstrated in patients with asthma. The number of $\mathrm{CD} 9^{+}$cells was not elevated. In our study, patients with asthma were in stable phase of disease and by definition the subjects in remission were without clinical symptoms all together. Therefore, disease activity should be regarded low in
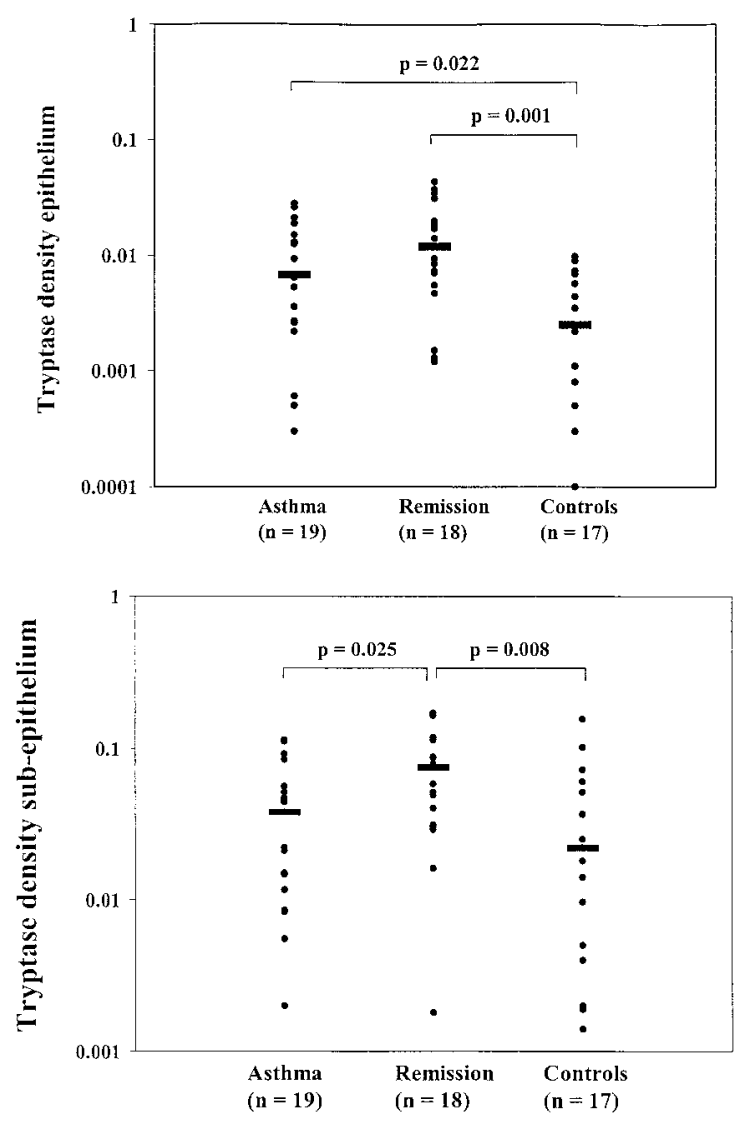

Figure 3. Ratio of area of tryptase staining and total area of epithelium (top panel) and sub-epithelium (bottom panel) in bronchial biopsy specimens from currently asthmatic subjects, subjects in clinical remission of atopic asthma, and healthy control subjects. Each closed circle represents one subject. Horizontal bars represent median values. Y-axis shows values logarithmically.

both groups. This may explain the absence of significantly elevated density of T-cells. However, we did find increased levels of activated cells, albeit not with an early marker of activation.

We found similar CD68 levels in all three groups. This may indicate that total macrophage numbers are relatively unimportant for asthma, and that a transformed and activated subset of these cells may be responsible for disease activity (20).

The relationship between markers of inflammation in bronchial biopsy specimens and other indices that presumably reflect distinct aspects of the inflammatory process, including peripheral blood eosinophils, eNO and the degree of BHR to various inhaled stimuli, is controversial. It has been proposed that determination of numbers of eosinophils in peripheral blood may help to indicate the level of airway inflammation (21). In the present study, blood eosinophil numbers correlated significantly with airway mucosal MBP density. Therefore, blood eosinophil cell numbers might serve as an indicator of eosinophilic airway inflammation in otherwise symptom-free subjects with a history of atopic asthma.

A relationship between elevated cell numbers and/or cell activity in bronchial biopsy specimens and BHR has been demonstrated in some other studies $(23,36)$. Especially BHR with AMP as the inhaled stimulus has been proposed as a useful marker reflecting at least part of the inflammatory process in asthma (37). We found a significant correlation between $\mathrm{PD}_{20} \mathrm{AMP}$ and MBP density in the airway wall mucosa in patients with current asthma and subjects in clinical remission of asthma. However, such a correlation could not be established 

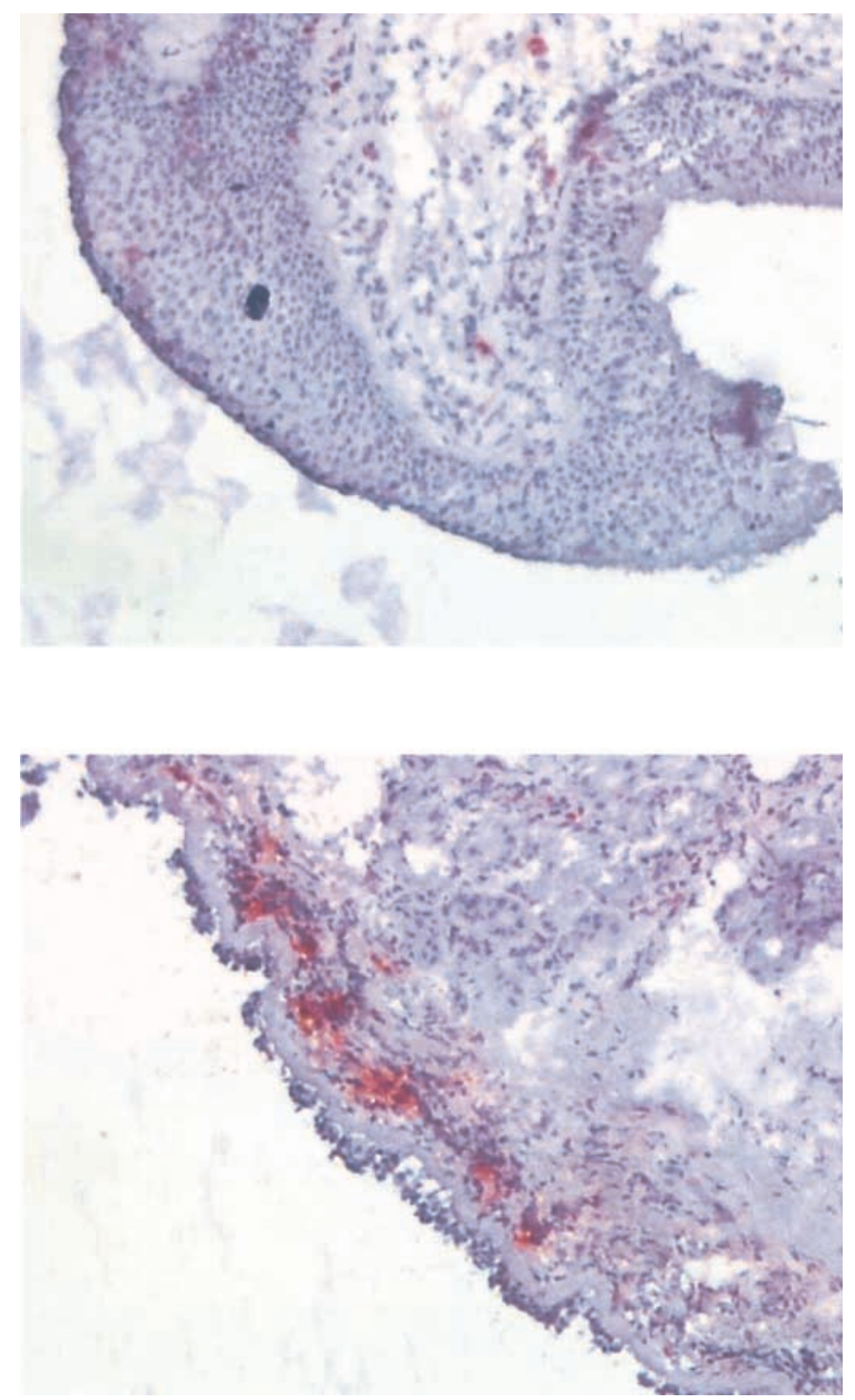

Figure 4. Bronchial biopsy specimen ( $\alpha$-tryptase) from a healthy control subject (top panel) and a subject in clinical remission of atopic asthma (bottom panel). Notice the increased tryptase-positive area (the red stain) and epithelial shedding in the subject in clinical remis-

between $\mathrm{PD}_{20} \mathrm{MCh}$ values and MBP density in the airway mucosa. This is in agreement with other reports where MCh responsiveness appeared to be unrelated to indices of inflammation determined in bronchial biopsy specimens, and more to structural changes of the airways $(22,38)$. Previously, we reported that levels of eNO were significantly correlated with $\mathrm{PD}_{20} \mathrm{AMP}$, but not with $\mathrm{PD}_{20} \mathrm{MCh}$ (11). This is in agreement with finding that both $\mathrm{PD}_{20} \mathrm{AMP}$ and eNO are related to the activity of cells known to play a role in the inflammatory process in asthma. In contrast, MCh acts directly on smooth muscle (SM) cells in the airway walls. Therefore, the response to $\mathrm{MCh}$ potentially reflects the structural changes found in asthma (39). This is supported by the fact that bronchial hyperreactivity to MCh may exist independently of active airway inflammation (40). The fact the MCh acts directly on SM cells may explain the absence of a correlation between BHR to $\mathrm{MCh}$ and RBM thickness. On the other hand, the positive correlation between BHR to AMP and RBM thickness may be
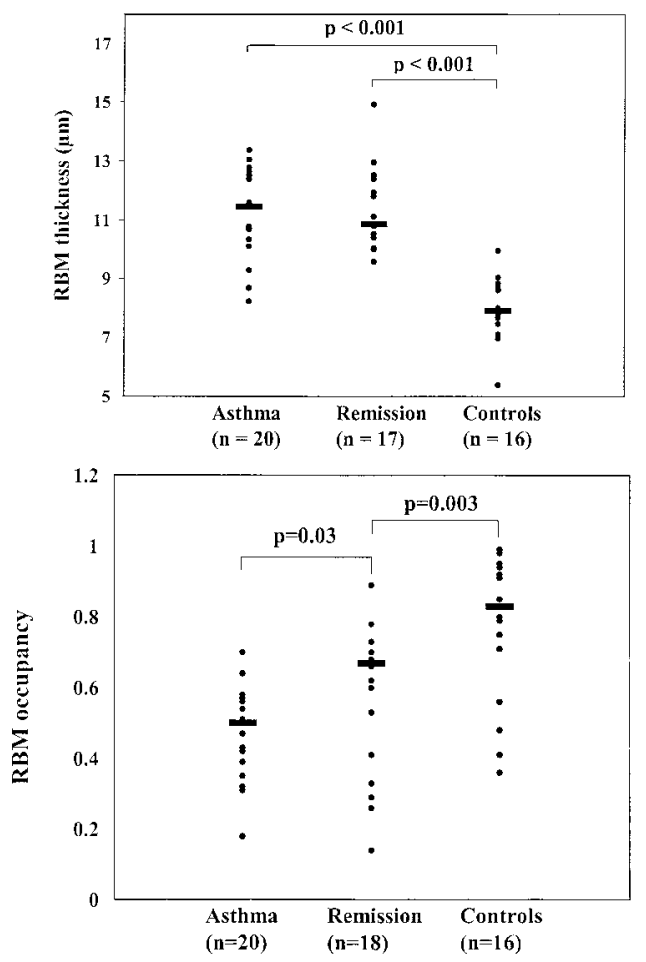

Figure 5. Thickness of the reticular basement membrane (RBM) (top panel) in biopsy specimens from currently asthmatic subjects, subjects in clinical remission of atopic asthma, and healthy control subjects. Horizontal bars represent median values. Occupancy of the reticular basement membrane (RBM) (bottom panel) with epithelium in biopsy specimens from currently asthmatic subjects, subjects in clinical remission of atopic asthma, and healthy control subjects. Results are plotted as ratio of the length of occupied RBM divided by the total membrane length. Horizontal bars represent median values.

explained by the presumed contribution of inflammatory mediators to the process of RBM remodeling.

Although epithelial desquamation may be an artifact of tissue sampling and not a true pathologic feature of the disease (41), we were able to demonstrate that the denudation of the RBM is much more progressive in patients with asthma than in subjects in remission. In subjects in remission, denudation is

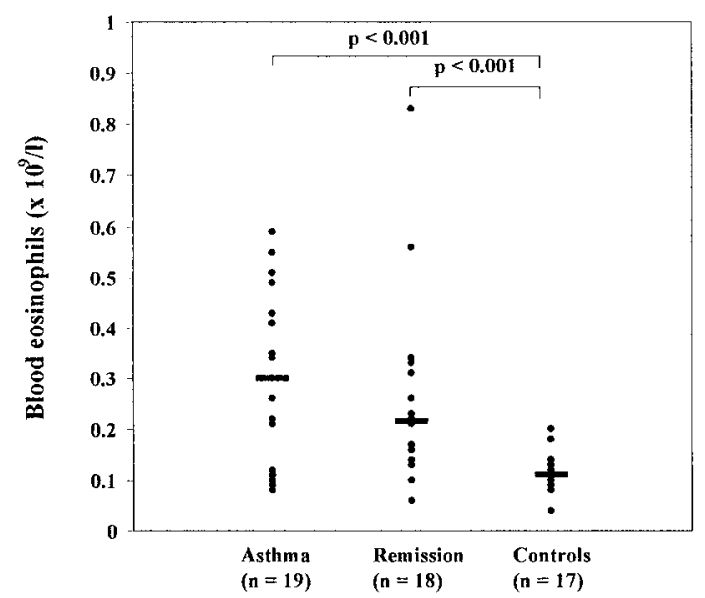

Figure 6. Eosinophil cell counts in blood samples from currently asthmatic subjects, subjects in clinical remission of atopic asthma, and healthy control subjects. Each circle represents one subject. Horizontal bars represent median values. 

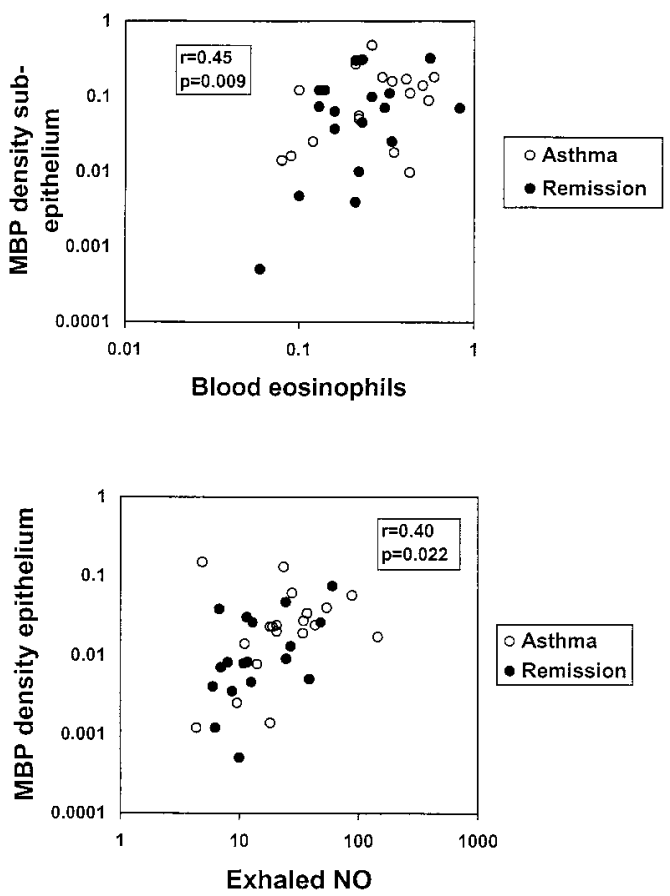

Figure 7. Correlation between blood eosinophil cell count and Major Basic Protein (MBP) density in subepithelium $(r=0.45, p=0.009)$ (top panel) and between exhaled Nitric Oxide (eNO) and MBP density in the bronchial epithelium ( $r=0.40, p=0.022$ ) (bottom panel) in the population of subjects in remission and currently asthmatic subjects. Each dot represents one subject.

more pronounced than in healthy control subjects. We hypothesize that the severity of airway disease determines the susceptibility of the epithelium for physical stress. Hence, the differences we observed between the groups may be a reflection of the overall integrity of bronchial epithelium in the asthmatic bronchus compared with the bronchus of subjects in remission and with that of healthy control subjects.

Exhaled NO levels have already been shown to correlate with blood and sputum eosinophilia in atopic children and adults with mild-intermittent asthma (42-44). Our study is the first to show a significant correlation between eNO levels and airway eosinophilia, as reflected by MBP density in the airway mucosa. Recently, eNO levels were reported not to correlate with mucosal eosinophils (45). This difference may be explained by methodological factors, which include patient selection and numbers.

Surprisingly, we found enhanced iNOS density in the airway wall mucosa from healthy control subjects compared with asthmatics and subjects in remission. This is not in agreement with the hypothesis of increased expression of iNOS in airway epithelium as the cause of elevated eNO $(12,46)$. We speculate that iNOS unrelated mechanisms, including enhanced diffusion of NO through damaged epithelium, or iNOS independent NO generation under conditions of airway acidity (47) may explain this finding in subjects with airways inflammation. Furthermore, other isoforms of NOS could account for elevated NO production. After an increase in NO, a negative feedback mechanism might result in lower iNOS levels in the airway mucosa from asthmatic subjects.

In conclusion, our study has shown ongoing airway inflammation and airway remodeling in adolescents in clinical remission of atopic asthma. We speculate that subclinical airway inflammation may well determine the risk of asthma relapse later in life. Furthermore, we hypothesize that subjects with evidence of airway inflammation during remission could possibly benefit from anti-inflammatory treatment in the shortand/or long-term. We propose that blood eosinophils, eNO and airway responsiveness to AMP, each reflecting distinct parts of the inflammatory process, may be useful in the long-term monitoring of asthmatic airway inflammation.

\section{References}

1. Panhuysen CI, Vonk JM, Koeter GH, Schouten JP, van Altena R, Bleecker ER, Postma DS. Adult patients may outgrow their asthma: a 25-year follow-up study. Am J Respir Crit Care Med 1997;155:12671272.

2. Barbee RA, Murphy S. The natural history of asthma. J Allergy Clin Immunol 1998;102:S65-72.

3. Kerrebijn KF, Fioole AC, van Bentveld RD. Lung function in asthmatic children after year or more without symptoms or treatment. $\mathrm{Br} \mathrm{Med} \mathrm{J}$ 1978;1:886-888.

4. Gruber W, Eber E, Steinbrugger B, Modl M, Weinhandl E, Zach MS Atopy, lung function and bronchial responsiveness in symptom-free paediatric asthma patients. Eur Respir J 1997;10:1041-1045.

5. Gillis HL, Lutchen KR. Airway remodeling in asthma amplifies heterogeneities in smooth muscle shortening causing hyperresponsiveness. $J$ Appl Physiol 1999;86:2001-2012.

6. Djukanovic R. Asthma: a disease of inflammation and repair. $J$ Allergy Clin Immunol 2000;105:522-526.

7. Vignola AM, Chanez P, Bonsignore G, Godard P, Bousquet J. Structural consequences of airway inflammation in asthma. J Allergy Clin Immunol 2000;105:514-517.

8. Fahy JV, Corry DB, Boushey HA. Airway inflammation and remodeling in asthma. Curr Opin Pulm Med 2000;6:15-20.

9. Laitinen A, Altraja A, Kampe M, Linden M, Virtanen I, Laitinen LA. Tenascin is increased in airway basement membrane of asthmatics and decreased by an inhaled steroid. Am J Respir Crit Care Med 1997; 156:951-958.

10. Hoshino M, Takahashi M, Takai Y, Sim J. Inhaled corticosteroids decrease subepithelial collagen deposition by modulation of the balance between matrix metalloproteinase- 9 and tissue inhibitor of metalloproteinase-1 expression in asthma. J Allergy Clin Immunol 1999;104: 356-363.

11. Van den Toorn LM, Prins JB, Overbeek SE, Hoogsteden HC, de Jongste JC. Adolescents in clinical remission of atopic asthma have elevated exhaled nitric oxide levels and bronchial hyperresponsiveness. Am J Respir Crit Care Med 2000;162:953-957.

12. Barnes PJ, Liew FY. Nitric oxide and asthmatic inflammation. Immunol Today 1995;16:128-130.

13. Saleh D, Ernst P, Lim S, Barnes PJ, Giaid A. Increased formation of the potent oxidant peroxynitrite in the airways of asthmatic patients is associated with induction of nitric oxide synthase: effect of inhaled glucocorticoid. Faseb J 1998;12:929-937.

14. Robinson DS, Bentley AM, Hartnell A, Kay AB, Durham SR. Activated memory $\mathrm{T}$ helper cells in bronchoalveolar lavage fluid from patients with atopic asthma: relation to asthma symptoms, lung function, and bronchial responsiveness. Thorax 1993;48:26-32.

15. Kon OM, Kay AB. T cells and chronic asthma. Int Arch Allergy Immunol 1999;118:133-135.

16. Bousquet J, Chanez P, Lacoste JY, Barneon G, Ghavanian N, Enander I, Venge P, Ahlstedt S, Simony-Lafontaine J, Godard P. Eosinophilic inflammation in asthma. N Engl J Med 1990;323:1033-1039.

17. Moqbel R, Barkans J, Bradley BL, Durham SR, Kay AB. Application of monoclonal antibodies against major basic protein (BMK-13) and eosinophil cationic protein (EG1 and EG2) for quantifying eosinophils in bronchial biopsies from atopic asthma. Clin Exp Allergy 1992; 22:265-273.

18. Church MK, Levi-Schaffer F. The human mast cell. J Allergy Clin Immunol 1997;99:155-160.

19. Rossi GL, Olivieri D. Does the mast cell still have a key role in asthma? Chest 1997;112:523-529.

20. Mautino G, Henriquet C, Gougat C, Le Cam A, Dayer JM, Bousquet J, Capony F. Increased expression of tissue inhibitor of metalloproteinase- 1 and loss of correlation with matrix metalloproteinase- 9 by macrophages in asthma. Lab Invest 1999;79:39-47.

21. Bousquet J, Corrigan CJ, Venge P. Peripheral blood markers: evaluation of inflammation in asthma. Eur Respir J Suppl 1998;26:42S-48S. 
22. Crimi E, Spanevello A, Neri M, Ind PW, Rossi GA, Brusasco V. Dissociation between airway inflammation and airway hyperresponsiveness in allergic asthma. Am J Respir Crit Care Med 1998;157:4-9.

23. Möller GM, Overbeek SE, van Helden-Meeuwsen CG, Hoogsteden HC, Bogaard JM. Eosinophils in the bronchial mucosa in relation to methacholine dose-response curves in atopic asthma. J Appl Physiol 1999; 86:1352-1356.

24. Sullivan P, Stephens D, Ansari T, Costello J, Jeffery P. Variation in the measurements of basement membrane thickness and inflammatory cell number in bronchial biopsies. Eur Respir J 1998;12:811-815.

25. Jeffery P. Structural alterations and inflammation of bronchi in asthma. Int J Clin Pract Suppl 1998;96:5-14.

26. Wilson JW, Li X. The measurement of reticular basement membrane and submucosal collagen in the asthmatic airway. Clin Exp Allergy 1997;27:363-371.

27. American Thoracic Society. Standards for the diagnosis and care of patients with chronic obstructive pulmonary disease (COPD) and asthma. ATS statement. Adopted by the ATS Board of Directors, November 1986. Am Rev Respir Dis 1987;136:225-244.

28. Laitinen LA, Laitinen A, Altraja A, Virtanen I, Kampe M, Simonsson BG, Karlsson SE, Hakansson L, Venge P, Sillastu H. Bronchial biopsy findings in intermittent or "early" asthma. J Allergy Clin Immunol 1996;98:S3-6; discussion S33-40.

29. Vignola AM, Chanez P, Campbell AM, Souques F, Lebel B, Enander I, Bousquet J. Airway inflammation in mild intermittent and in persistent asthma. Am J Respir Crit Care Med 1998;157:403-409.

30. Holgate ST. The immunopharmacology of mild asthma. J Allergy Clin Immunol 1996;98:S7-16; discussion S33-40.

31. Laitinen LA, Laitinen A, Haahtela T. Airway mucosal inflammation even in patients with newly diagnosed asthma. Am Rev Respir Dis 1993;147:697-704.

32. Bradley BL, Azzawi M, Jacobson M, Assoufi B, Collins JV, Irani AM, Schwartz LB, Durham SR, Jeffery PK, Kay AB. Eosinophils, T-lymphocytes, mast cells, neutrophils, and macrophages in bronchial biopsy specimens from atopic subjects with asthma: comparison with biopsy specimens from atopic subjects without asthma and normal control subjects and relationship to bronchial hyperresponsiveness. $J$ Allergy Clin Immunol 1991;88:661-674.

33. Bentley AM, Meng Q, Robinson DS, Hamid Q, Kay AB, Durham $\mathrm{SR}$. Increases in activated T lymphocytes, eosinophils, and cytokine mRNA expression for interleukin-5 and granulocyte/macrophage colony- stimulating factor in bronchial biopsies after allergen inhalation challenge in atopic asthmatics. Am J Respir Cell Mol Biol 1993;8:35-42.

34. Frew AJ, St-Pierre J, Teran LM, Trefilieff A, Madden J, Peroni D, Bodey KM, Walls AF, Howarth PH, Carroll MP, Holgate ST. Cellular and mediator responses twenty-four hours after local endobronchial allergen challenge of asthmatic airways. J Allergy Clin Immunol 1996; 98:133-143.

35. Gratziou C, Carroll M, Montefort S, Teran L, Howarth PH, Holgate ST. Inflammatory and T-cell profile of asthmatic airways 6 hours after local allergen provocation. Am J Respir Crit Care Med 1996;153:515-520.

36. Koshino T, Arai Y, Miyamoto Y, Sano Y, Itami M, Teshima S, Hirai K, Takaishi T, Ito K, Morita Y. Airway basophil and mast cell density in patients with bronchial asthma: relationship to bronchial hyperresponsiveness. J Asthma 1996;33:89-95.

37. Polosa R, Holgate ST. Adenosine bronchoprovocation: a promising marker of allergic inflammation in asthma? Thorax 1997;52:919-923.

38. Djukanovic R, Wilson JW, Britten KM, Wilson SJ, Walls AF, Roche WR, Howarth PH, Holgate ST. Quantitation of mast cells and eosinophils in the bronchial mucosa of symptomatic atopic asthmatics and healthy control subjects using immunohistochemistry. Am Rev Respir Dis 1990;142:863-871.

39. Chetta A, Foresi A, Del Donno M, Consigli GF, Bertorelli G, Pesci A Barbee RA, Olivieri D. Bronchial responsiveness to distilled water and methacholine and its relationship to inflammation and remodeling of the airways in asthma. Am J Respir Crit Care Med 1996;153: 910-917.

40. Perin PV, Weldon D, McGeady SJ. Objective indicators of severity of asthma. J Allergy Clin Immunol 1994;94:517-522.

41. Ordonez C, Ferrando R, Hyde DM, Wong HH, Fahy JV. Epithelial desquamation in asthma. Artifact or pathology? Am J Respir Crit Care Med 2000;162:2324-2329.

42. Horvath I, Donnelly LE, Kiss A, Kharitonov SA, Lim S, Fan Chung K, Barnes PJ. Combined use of exhaled hydrogen peroxide and nitric oxide in monitoring asthma. Am J Respir Crit Care Med 1998;158:10421046.

43. Jatakanon A, Lim S, Kharitonov SA, Chung KF, Barnes PJ. Correlation between exhaled nitric oxide, sputum eosinophils, and methacholine responsiveness in patients with mild asthma. Thorax 1998;53:91-95.

44. Piacentini GL, Bodini A, Costella S, Vicentini L, Mazzi P, Sperandio $\mathrm{S}$, Boner AL. Exhaled nitric oxide and sputum eosinophil markers of inflammation in asthmatic children. Eur Respir J 1999;13:13861390 .

45. Lim S, Jatakanon A, Meah S, Oates T, Chung KF, Barnes PJ. Relationship between exhaled nitric oxide and mucosal eosinophilic inflammation in mild to moderately severe asthma. Thorax 2000; 55:184-188.

46. Hamid Q, Springall DR, Riveros-Moreno V, Chanez P, Howarth P, Redington A, Bousquet J, Godard P, Holgate S, Polak JM. Induction of nitric oxide synthase in asthma. Lancet 1993;342:1510-1513.

47. Hunt JF, Fang K, Malik R, Snyder A, Malhotra N, Platts-Mills TA, Gaston B. Endogenous airway acidification. Implications for asthma pathophysiology. Am J Respir Crit Care Med 2000;161:694-699. 